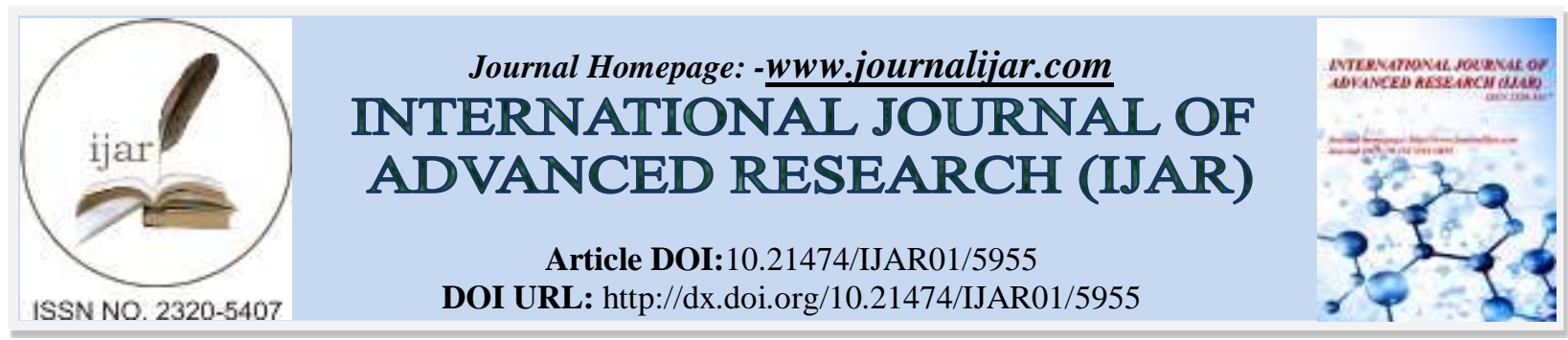

RESEARCH ARTICLE

\title{
IDENTIFICATION, CHARACTERIZATION AND DOCUMENTATION OF MEDICINAL AND WILD EDIBLE PLANTS IN KASHAF KEBELE, MENGE WOREDA, BENISHANGUL GUMUZ, ETHIOPIA.
}

Dessalegn Ayele ${ }^{1}$ and Deressa Negasa ${ }^{2}$.

1. Assosa University, College of natural and computational Science, Department of Biology.

2. Assosa University, College of Agriculture, department of Agronomy.

\section{Manuscript Info}

Manuscript History

Received: 03 October 2017

Final Accepted: 05 November 2017

Published: December 2017

Key words:-

Aliments, Indigenous knowledge, local communities, Medicinal, Wild edible

\section{Abstract}

This study was conducted on Identification, Characterization and Documentation of Medicinal and Wild Edible Plants in KashafKebele, MengeWoreda, and BenishangulGumuz. A study sites was purposively selected in and around the adaptation site that established by Assosa Environmental Protection Authority and a variety of ethnobotanical methods were applied including semi-structured interviews, field guided observations, group discussion and interview with local healers and then analyzed by descriptive statistics. A total of 60 plant species have been identified of which 32 (53\%) are only medicinal plants, 21 (35\%) are only wild edible plants. and $7(12 \%)$ species are used for both medicinal and edible. About $33(84.62 \%)$ species are used to treat only human ailments whereas 6 (15.38\%) species are used to treat both human and livestock ailments. About 23 types of human disease and 5 types of livestock ailments were treated by these plants. Highest number of species were collected from Fabaceae Family 9 (15\%) followed by Combretaceae, Malvaceae, Moraceae, Anacardiaceae and Tiliaceae with each of them containing 3 (5\%) plant species. Most of plant species had the tree life forms/habitats. Different parts of the plants like leaf, bark, root, stem, flower, seed and fruits are used for medication and edibility. A remedy from these plant parts is mostly prepared as fresh by mixing with water as solvent after ground. Fruit 21 (35\%)is accounted to be the most edible plant parts and mostly taken as raw. Elderly people and local healers of had ample knowledge on preparation of medicinal and WEPs practices along with the ecological distribution of plants as compared to young generation. Thesemedicinal and WEPs had multipurpose values however, local communities had less awareness on its conservation and multipurpose values. Therefore, plants found in and around kashafkebele are very important as medicinal and edible foods for treating human and livestock ailments as well as sources of food during normal times and when there is shortage of food. Moreover, indigenous knowledge was hidden among the local people. Therefore, government should give more attention to this indigenous knowledge to apply to modern knowledge of science and technology and implement different conservation strategies. 


\section{Introduction:-}

Plants are the basis of life on earth which play central role to people's livelihoods. People utilize plants for sources of thatch for huts, timber for boats, fibers for cordage, textile and dyes starting at early stages of human prehistory. Yet these uses seem less important in comparison with use of plants for medicine and food. People in different parts of the world depend on plant resources for their basic needs for food, clothes and shelter occurring in their environments (Balick and Cox, 1996). The indigenous people have continuously developed this knowledge of traditional plant uses and plant resource management for prolonged interactions with the natural world. Plants have thus been indispensable sources of both preventive and curative traditional medicine preparations for human beings and livestock since ancient times.

Thousands of species of wild fruits, leaves, seed, root and tuber are consumed as food worldwide. Wild edible plants (WEP) provide staple food for indigenous people, serve as complementary food for non-indigenous people and offer an alternative source of cash income for poor communities (Juet al., 2013).WEPs play an important role in ensuring food security and improve the nutrition in the diets of many people in developing countries (FAO, 2010).

Since traditional knowledge on WEPs is being eroded through acculturation and the loss of plant biodiversity along with indigenous people and their cultural background, promoting research on wild food plants is crucial in order to safeguard this information for future societies (ErmiasLulekalet al., 2011).

Medicinal plants have important contributions in the healthcare system for the majority of the rural population. They also play a key role in the development and advancement of modern studies by serving as a starting point for the development of novelties in drugs (Cox and Balick, 1996; Flaster, 1996; Pramono, 2002). The knowledge and use of plants is an integral part of many ethnic rural people of Ethiopia. However, the extent of which has not yet been studied in depth (Abbink, 1995). Likewise, documentation and analysis of medicinal and wild edible plants are not investigated fully in the selected Woredas. Therefore, this study will explore the indigenous knowledge of medicinal and wild edible plants in these areas.

\section{Material and methods:-}

\subsection{Description of the study area:}

The research was conducted from 2016-2017 in MengeWoreda at specific place of Kashaf Kebele. Menge woreda is located in Benishangul-Gumuz Regional State (BGRS), which is $661 \mathrm{~km}$ from Addis Ababa. The indigenous population of BGRS consists of five ethnic groups: Gumuz, Berta, Shinasha, Mao and Komo accounting for 23.4\%, $26.7 \%, 7.0 \%, 0.6 \%$ and $0.2 \%$ of the total population, respectively (AWADO, 2015).

The woreda has wider land forms, plains, plateaus valleys and mountains. The altitude range of the woreda is between $900 \mathrm{~m}$ and 1560 m.a.s.l. Most of the agro-ecological zone of Menge woreda is kola, but it consists least of ecological zone of "Weyna Dega". The average temperature of the woreda is $27^{0} \mathrm{C}$. The rainfall pattern is monomodal rainfall distribution. The rainy season starts in May and extends to October (AWADO, 2015).

\subsection{Site selection}

The site was purposively selected due to the existence of adaptation site of medicinal and wild edible plants at kashafkebele which was established by Assosa Environmental Protection Association and the surrounding is ample with different plant species great economic and social value for the community.

\subsection{Informant selection}

Key informants were systematically selected from the study site by using information and recommendations from the local kebele administrators and kebele agricultural officials, knowledgeable elders and religious leaders as well as the local community. Accordingly, a total of 62 informants (42 male and 20 female) aged of 18 to 95 that included knowledgeable person on medicinal plants (local doctor) were selected.

\subsection{Ethnobotanical data collection}

Ethno-botanical data were collected following Martin (1995), Cotton (1996) and Cunningham (2001). Accordingly, semi-structure interview, group discussion, guided field observation and interview with key informant (local doctor) were applied to obtain Ingenious Knowledge of the local people on medicinal and wild edible plants. 


\subsection{Data Analysis}

Data were analyzed following survey and analytical tools for ethnobotanical methods recommended by Martin (1995), Alexiades (1996) and Cotton (1996). Accordingly, ethnobotanical ranking and scoring were analyzed and interpreted by descriptive statistics. Data from Focus Group Discussion and Interviews were also analyzed both qualitatively and quantitatively based on their nature.

\section{Result and Discussion:-}

\subsection{Species diversity}

A total of 60 species, 53 genera and 33 families of medicinal and wild edible plants were recorded in the area.. The total number of plant species recorded as medicinal and wild food plant species indicated that the study area has substantial amount of useful plants and diverse source of medicinal and wild food plants. The diversity of these medicinal and wild edible plants might be due to the suitability of environmental condition for different types of plant species. This finding is a good indicator for the presence of a considerable diversity of plant species in the study area.

The Fabaceae family contains 9 (15\%) species, followed by Combretaceae, Malvaceae, Moraceae, Anacardiaceae and Tiliaceae with each of them contains $3(5 \%)$ species. These families are also known to have largest number of species in Ethiopia based Flora of Ethiopia and Eritrea volume 8. Similar finding was observed by Getnet (2011) and FissehaMesfinet al., 2009 indicated that Asteraceae and Fabaceae family accounted the largest species in their study. From 60 collected plant species, about $32(53.33 \%)$ plant species were used for only medicinal purposes whereas about $21(35 \%)$ of plant species are used for only edible food and about 7 (11.67\%) plant species were used for both medicinal and food purpose (Figure 1).

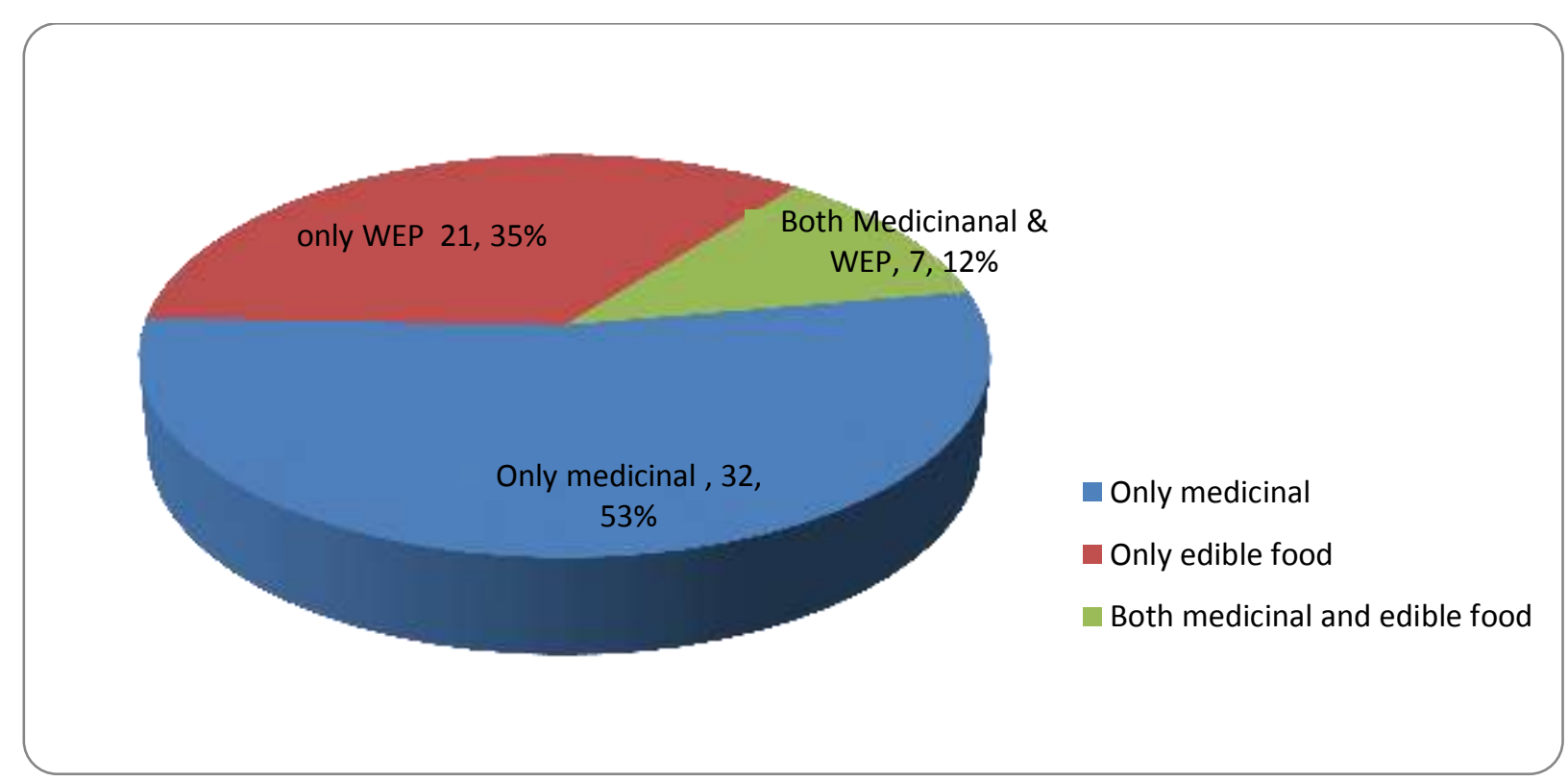

Figure 1:-Number and percentage of medicinal plants, wild edible plants and both in the study area

\subsection{Life Forms of medicinal and wild edible plants}

The medicinal and edible plants of the area have different life forms and most are tree with 37 species $(61.67 \%)$ followed by shrub 15 (25\%) and runner and grass forms accounted each of them 1 (1.67\%) plant species (Figure 2). Similarly Assegid and Tesfaye, 2011 reported that of the collected wild edible plants trees comprised 18 species $(60 \%)$ and the remaining 12 species (40\%) were shrubs. Tilahun \& Mirutse (2010) also reported that ethnobotanical study of wild edible plants in Kara and Kwego agree with this result. However, disagrees with the report from Derashe and Kucha District (Kebu Balemie \&Fassil Kebebew, 2006), which revealed that wild edible materials are largely collected from shrubs. These differences might be due environmental difference. 


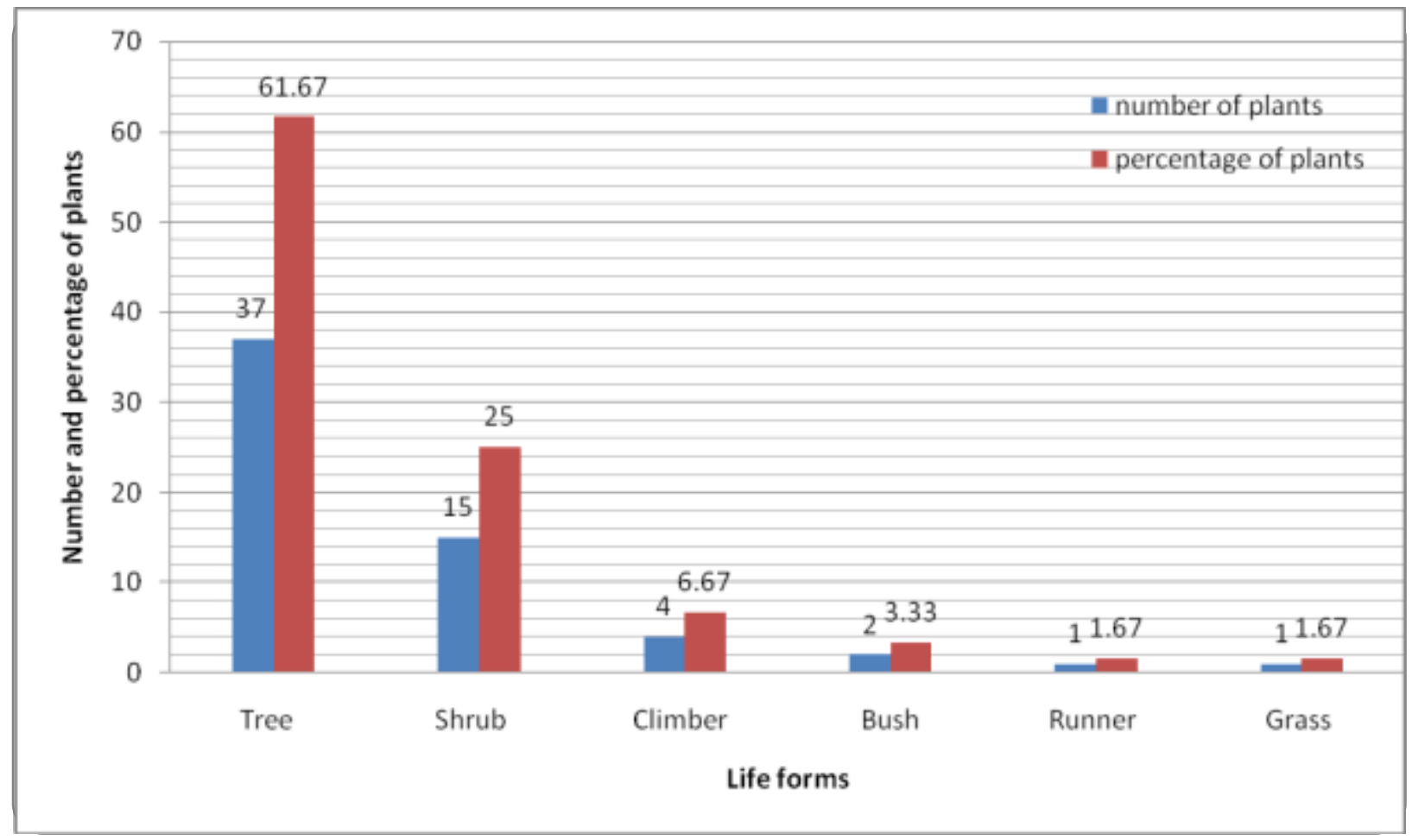

Figure 2:-Life forms of medicinal and edible plants in the study area

\subsection{Parts of Plants used for preparation of remedies and food}

The present study indicated that $21(35 \%)$ plant species the fruit parts is used followed by root $11(18.33 \%)$ and leaves $11(18.33 \%)$, respectively (Table 1). This result revealed with (Assegid and Tesfaye, 2011) that reported as $80 \%$ of consumed edible parts are fruits. The dominance of fruits as edible parts has also been reported in most previous studies that undertaken in Ethiopia (Zemede \& Mesfin, 2005; Getachew et al., 2005; Kebu \& Fassil, 2006; Tilahun \& Mirutse, 2010). But the result of Endalew Amenu, 2007 and Fisseha Mesfinet al., 2009 reported that roots are mostly used parts for medicinal and edible purposes. This variation might be due to the variation of plant species in adapting to different ecological zone and culture of the people in different area.

Table 1:-Plant parts used for the preparation of remedies and food

\begin{tabular}{|l|l|l|}
\hline parts used & Number of plants & Percentage \\
\hline Fruit & 21 & 35.00 \\
\hline Root & 11 & 18.33 \\
\hline Leaf & 11 & 18.33 \\
\hline Bark & 4 & 6.67 \\
\hline Woody stem & 2 & 3.33 \\
\hline Flower & 2 & 3.33 \\
\hline Fruit and leaf & 2 & 3.33 \\
\hline Fruit and bud & 1 & 1.67 \\
\hline Root and leaf & 1 & 1.67 \\
\hline Root and flower & 1 & 1.67 \\
\hline Root and fruit & 1 & 1.67 \\
\hline Root and bark & 1 & 1.67 \\
\hline Leaf, fruit and root & 1 & 1.67 \\
\hline Seed & 1 & 1.67 \\
\hline Total & 60 & 100 \\
\hline
\end{tabular}




\subsection{Medicinal Plants of the study area}

Thirty nine (39) species of medicinal plants belonging to 22 families were identified from the study area (Figure 3). Most of the species are reported from Fabaceae family. This indicated that, medicinal plants are more in number as compare to edible plants. The local people had in-depth indigenous knowledge on uses of plant remedies for treatment of human diseases and livestock ailments from natural vegetation. Similar to this other studies carried out in northwestern Ethiopia among the people of Shinasha, Agew-awi and Amhara, the family Fabaceae was reported to have the largest number of plant species used for medicinal purposes (Gidey, 2007). Awaset al. (2007) also reported that the Fabaceae is the most widely used plant family among the Berta and Gumuz people.

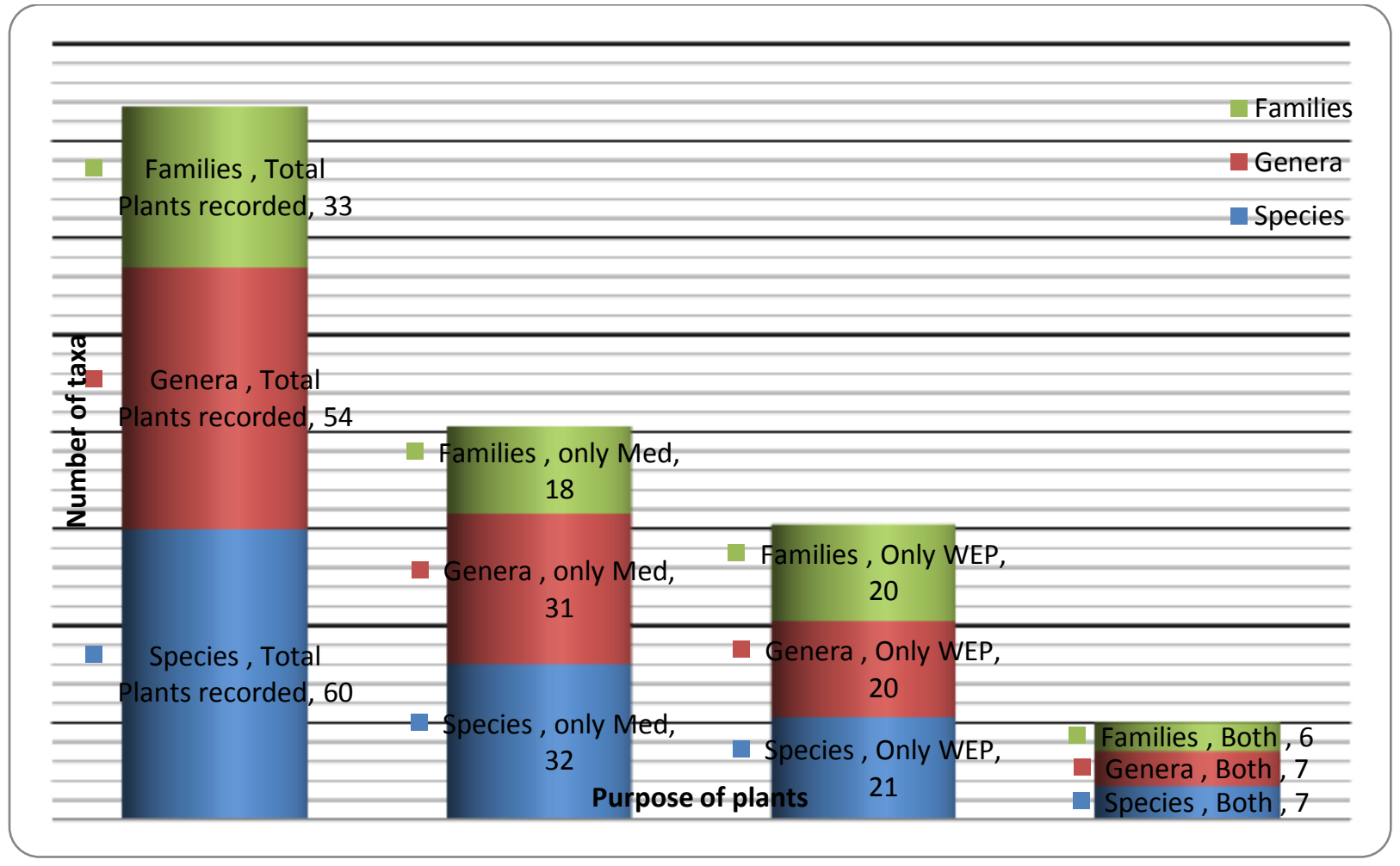

Figure 3:-Categories of medicinal and WEP plants in the study area

\subsection{Disease treated by traditional medicine from plants:}

These medicinal plants are used to treat about 23 types of human ailments and 5 types of livestock ailments. Most of them, about seven (7) plant species are used to treat Diarrhea (Tekmat) followed by six (6) plant species used to treat Common cold (Gunfan) and Gastric (Chogara) respectively (Table 8 and Table 9). Similar to this finding Teferi, 2009 reported that the highest numbers of plant species were used to treat Diarrhea disease followed by malaria, evil eye, Libhimem/Lib dikam, headache, Gunfanand Yehistanatbeshitain komoshworeda.

Table 2:- Types of human ailments treated by medicinal plants in the study area

\begin{tabular}{|l|l|l|l|}
\hline Type of human ailments & Number of plants & Type of human ailments & Number of plants \\
\hline Diarrhea (Tekmit) & 7 & Snake beating & 1 \\
\hline Gastric & 6 & "Ginti" beating & 1 \\
\hline Common cold & 6 & Devil sprit & 1 \\
\hline Malaria & 5 & Epilepsy (Yemitilbeshita) & 1 \\
\hline Wound healing & 3 & Fever & 1 \\
\hline Headache & 2 & Eye disease & 1 \\
\hline Dem mefseslemakom & 2 & Teeth disease & 1 \\
\hline "Wetetebeshita" & 2 & Ear lesion & 1 \\
\hline Broken and swollen healing & 2 & Nausea & 1 \\
\hline Hodkurtet & 1 & "Yehitsanebeshita" & 1 \\
\hline
\end{tabular}




\begin{tabular}{|l|l|l|l|}
\hline Typhoid & 1 & Urine increment & 1 \\
\hline Abdominal disorder (Hodhimem) & 1 & & \\
\hline
\end{tabular}

\subsection{Condition of preparation, dosage and time of taking medicinal plants}

These medicinal plants are prepared in the form of fresh or dried. However, fresh form has the highest acceptance by many informants. As some informants reported for certain plant species which are seasonal and not ever green, preservation of remedies was recommended and the same finding was reported by Endalew, 2007 and Getnet, 2011. These fresh or dried plant materials can be taken by mixing with water or other ingredients or alone. More than $60 \%$ of the remedies were prepared by mixing with water. Similar findings were reported by Abdu and Hamed, 1982 and Etana, 2007.

The dosage and time of taking these medicines were varies based on age, level of disease and the capacity of patients as judged by the local healers. The local people of the study area were adopted different traditional ways of determining dosage like coffee cup, water glass, finger length (bark, root and stem), pinch (powdered plant medicine), numbers (leaves, seeds and fruits) and one hand for solid materials. However, as most of informants were reported, around $41.67 \%$ of remedies were given one coffee cup for elder and half of coffee cup for infants in the form of solution after it mixed with water or other solvents and more than $50 \%$ of the remedies were taken once when the disease was occurred first time. DawitAbebe (1986) and EtanaTolesa (2007) also reported lack of precision and standardization on traditional medicines is one of the drawbacks of traditional health care system.

\subsection{Plants used for food and their categories}

A total of 28 wild edible species within 22 families were recorded in the study area. A highest number of wild food plants are reported in the families of Moraceae three species (10.71\%) followed by Fabaceae, Polygonaceae, Myrtaceae and Malvaceae two species (7.14\%) of each. The remaining 17 families contributed one species (3.57\%) each.

Also the result by different researchers in different part of Ethiopia supports the finding of the current work (Getnet, 2011; AbrhaTesfay, 2008; Haile Yinegeret al., 2008 and SeyoumGetaneh, 2009; and BehailuEtana, 2010), (TilahunTeklehaimanot\&MirutseGiday, 2010).

\subsection{Distribution and Current Situation of Medicinal and WEPs}

About $32(53.33 \%)$ plant species were found in anywhere/location whereas 23(38.33\%), 4 (6.67\%) and 1 (1.67\%) of plant species were found only in the forest, only around the riverside and only in home garden, respectively (Table 3 ). In addition to this about $73.33 \%$ of plant species was widely distributed whereas $26.67 \%$ was rarely distributed in the study area. This finding is agreed with (Kebu and Fassil, 2006) that reported from collected plant species most of them are distributed in wide environmental locations.

Table 3:-Area of availability of medicinal and edible food plants in the study area

\begin{tabular}{|l|l|l|}
\hline Area of availability & Number of plants & Percentage (\%) \\
\hline $\begin{array}{l}\text { Any where (includes forest, garden, } \\
\text { around the farm land, road and riverside) }\end{array}$ & 32 & 53.33 \\
\hline Only forest & 23 & 38.33 \\
\hline Only riverside & 4 & 6.67 \\
\hline Only home garden & 1 & 1.67 \\
\hline Total & 60 & 100 \\
\hline
\end{tabular}

\subsection{Availability Seasons of medicinal and edible plants}

These medicinal or wild edible plants were available in different seasons. About 28 (46.67\%) of plant species were found in all season followed by about $16(26.67 \%)$ and $10(16.67 \%)$ of plant species were found only in winter and summer, respectively (Figure 4). This might be due to the fact that most of medicinal and wild edible plants are perennial plants. 


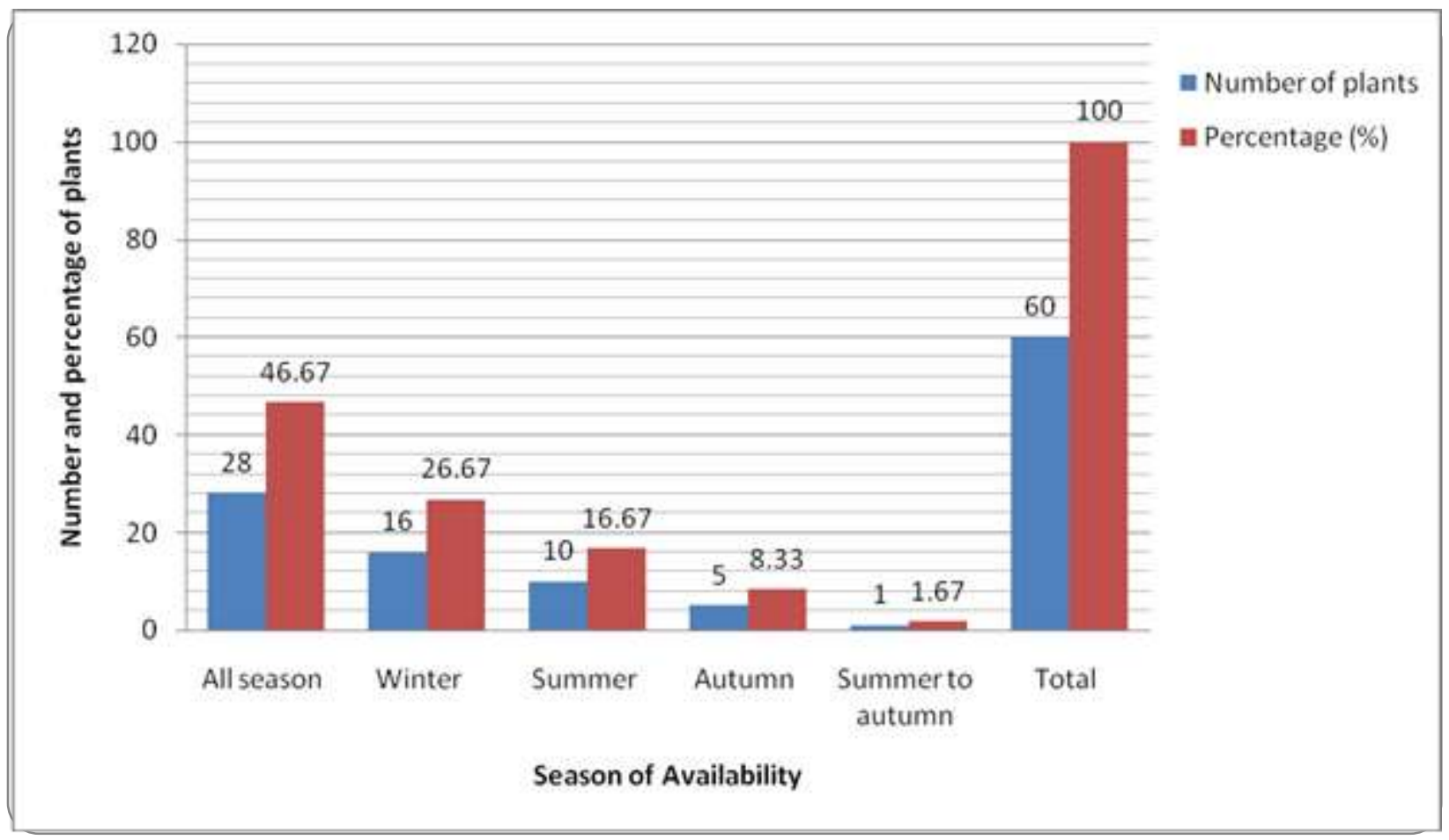

Figure 4:-Season of availability of medicinal and wild edible food plants in the study area.

\subsection{Conservation status of Medicinal and wild edible plants}

As local people especially elder informants reported before the past ten to fifteen years in the study area full of natural vegetation were found around the farm land, forest, and riverside as well as wealth of plant species in number and diversity was exist. Today these medicinal and wild edible plant species were not easily available in the area due to the modification of plant habitats and depletion of plant species.

Increment of population number in the study area and lack of awareness; deforestation, expansion of agricultural activities, for firewood, for charcoal preparation and for house construction were highly expanded extremely depleting medicinal and wild edible plant species from the study area. Among these problems, most informants perceived that agricultural expansion that include both land cultivation and livestock production was the main factor $(45.45 \%)$ that threat medicinal and wild food plants followed by firewood which accounted about $27.27 \%$ whereas construction accounted for the least ones (9.09\%). The challenges existing in conservation of medicinal and wild edible plants are also reported by different researchers in studies (Tesfaye and Assagid, 2011; Guinand\&DechassaLemessa, 2000; TigistWondimuet al., 2006). Moreover, EtanaTolesa (2007) also reported that agricultural expansion was the most important factor depletion of medicinal and wild edible plants.

\section{Conclusion:-}

The present study indicates that Kashafkebele was plenty with a diversity of medicinal and wild edible plants that serve the communities for different purposes. Knowledge and uses of these plants for the treatment of various human and livestock ailments and for food purposes are still a major part of local peoples' livelihood and culture. However, currently due to different factors transfer of this indigenous knowledge from generation to generation is become declined.

There are different life forms (tree, shrub, bush, climber, grass and runner) of these medicinal and wild edible plants in the study area. From different parts of these medicinal and wild edible plants, fruits are the most plant parts that used for medicinal purposes as well as for edible food. Moreover, these medicinal and edible food plants had multipurpose values like for feed of animal, house construction, furniture, charcoal preparation, fire wood, fences, shade, soil conservation, protect change of environmental condition and provide an opportunity to supplement household incomes. 
Still now local people had a depth indigenous knowledge on uses of plant remedies for treatment of their own diseases and livestock ailments by using their surrounding natural vegetation. Diarrhea (Tekmit), Common cold (Gunfan), Gastric (Chogara) and malaria disease are commonly treated by most medicinal plants found in the study area. These medicinal plants are prepared in different ways (ground, chewed, chopped, powdered, boiled, fired, direct eating, fluid and juice) whereas ground takes the lion share.

Most of the remedies are prepared as soon as the health problem occurs using the available fresh forms by mixing with different solvents or alone. The dosage and time of taking these medicines were varies based on age, level of disease and the capacity of patients as judged by the local healers. People living in the study area are mostly consumed these wild edible plants in the form of fresh without any further processing. Most numbers of wild edible plants are used as supplementary in the regular food supply and food scarcity occurred.

Due to expansion of modernization, many people preferred modern medicine and foods as compare to locally available medicinal and wild edible foods. Deforestation of these plants for expansion of agricultural activities, for firewood, for charcoal preparation and for house construction are the major factors that depleting medicinal and wild edible plants.

\section{Recommendations:-}

Based on the results of the study, the following recommendations are forwarded:

- All available medicinal and wild edible plants in the study area are not totally collected due to seasonality of some plants. Therefore, further investigation should be undertaken to identify all medicinal and wild edible plants in the study area.

- Almost all medicinal and wild edible plants are found on the forest, river side and range land areas. Therefore, local communities should be encouraged to cultivate the medicinal and wild edible plants on their own land.

- As the study indicated, there are high potential of using wild edible and medicinal plants in the local area for human benefits but, the amount/dosage and rate of the remedies and edible foods are not known exactly. Further investigations on pharmacological and nutritional screening should be done to prove the validity of traditional health care practices as well as wild foods.

- Currently due to different factors like modernization, transfer of indigenous knowledge from generation to generation is become declined. Therefore, awareness should be given for new generation on the uses and preparation of medicinal plants for the treatment of various human and livestock ailments and wild edible plants for food purposes.

- Since some of the highly valued medicinal and wild edible plants are being depleting due to deforestation of these plants for expansion of agricultural activities, for firewood, for charcoal preparation and for house construction. Specific medicinal and wild edible plant conservation strategy should be formulated and implemented for long term management by both local people and government

- Cultural management practices that have been implementing on conservation of medicinal and wild edible plants by local communities should be encouraged.

- Attention should be given to standardization of measurements and hygiene of the medicines and foods made from plants by training both the healers and other members of the local community.

\section{References:-}

1. Abbink, J. (1995). Medicinal and Ritual Plants of the Ethiopian Southwest: An Account of Recent Research. Indigenous Knowledge andDevelopment Monitor3(2):6-8.

2. Abdu, H. S. and Hamed, S. (1982). The complete book of home remedies. Orient Papers Backs, pvt. Ltd. New Deli, Bomay. Pp. 25-159.

3. Aberoumand, A. (2009). Nutritional evaluation of edible Portulacaoleracea as plant food. Food Analyt. Meth. 2: 204-207.

4. AbrhaTesfay (2008). Ethnobotanical study of Dessa Forest, North-eastern Escarpment of Ethiopia, with Emphasis on Use and Management of Forest Resources by the Local People. M.Sc. Thesis, Addis Ababa University, Addis Ababa.

5. Afolayan, A. and Jimoh, F. (2009). Nutritional quality of some wild leafy vegetables in South Africa.International Journal of Food Science and Nutrition 60: 424-431.

6. AsayegnBekele and Abiy Musa (2009). Ethnoveterinary practice in Chiro District, western Hararge, Ethiopia. Pharmacology on line 2009, 1:128-139. 
7. AsfawZemede (2009). The future of wild food plants in southern Ethiopia: Ecosystem conservation coupled with enhancement of the roles of key social groups. ActaHorticulturae 806: 701-707.

8. AssegidAssefa and TesfayeAbebe, 2011. Wild edible trees and shrubs in the semi-arid lowlands of Southern Ethiopia. Southern Agricultural Research Institute, Hawassa, EthiopiaJournal of Science and Development 1 (1): $1-15$

9. Awas T, Asfaw Z, Nordal I, Demissew S: Ethnobotany of Berta and Gumuz people in western Ethiopia. In Plant Diversity inWestern Ethiopia: Ecology, Ethnobotany and Conservation PhD Dissertation:University of Oslo, Norway; 2007.

10. Balick, M.J. and Cox. P.A. (1996). Plants, People, and Culture. The Science of Ethnobotany. New York: Scientific American Library.

11. BehailuEtana (2010). Ethnobotanical Study of Traditional Medicinal Plants of GomaWereda, Jima Zone of Oromia Region, Ethiopia. M.Sc. Thesis, Addis Ababa University, Addis Ababa.

12. Belcher, B., Ruíz-Pe'rez, M. and Achidiawan, R. (2005). Global patterns and trends in the use and management of commercial NTFPs. J. World Dev. 33: 1435-1452.

13. Bell J. 1995. The hidden harvest in seeding. The Quarterly Newsletter of genetic resources. Action International, 1-8.

14. Beluhan, S. and Ranogajec, A. (2010). Chemical composition and non-volatile components of Croatian wild edible mushrooms. Food Chemistry 124: 1076-1082.

15. Bharucha, Z. and Pretty, J. (2010). The roles and values of wild foods in agricultural systems. Phil. Trans. $R$. Soc. B. 365: 2913-2926.

16. Convention on Biological Diversity (CBD) (2006). Traditional Knowledge, Innovations and Practices.http://www.biodiv.org/programmes/socio-eco/traditional/default.aspx Accessed July 2006.

17. Cotton, C.M. (1996). Ethnobotany: Principles and Applications. Chichester: John Wiley and Sons Ltd.

18. DawitAbebe (1986). Traditional medicine in Ethiopia: the attempts being made to promote it for effective and better utilization. SINET 9:61-69.

19. EndalewAmenu (2007). Use and Management of Medicinal plants by Indigenous People of Ejaji Area (ChelyaWoreda), West Shoa, Ethiopia: An Ethnobotanical Approach. M.Sc. Thesis, Addis Ababa University, Addis Ababa.

20. ErmiasLulekal, ZemedeAsfaw, EnsermuKelbessa and Damme, V. P. (2011).Wild edible plants in Ethiopia: a review on their potential to combat food insecurity.

21. EnsermuKelbessa, SebsebeDemissew, ZewdeWoldu,.and Edwards, S. (1992). Some threatened Endemic Plants of Ethiopia.In: The status of some plants in parts of tropical Africa, East and Central Africa.

22. EtanaTolesa (2007). Use and Conservation of Traditional Medicinal Plants by Indigenous People in GimbiWoreda, Western Wellega, Ethiopia.

23. FissehaMesfin, SebsebeDemissew and TilahunTeklehaymanot (2009). An ethnobotanical study of medicinal plants in WonagoWoreda, SNNPR, Ethiopia. J. Ethnobio. andEthnomed.5:28.

24. Fantahun, M. and Hager, H. (2010). Integration of indigenous wild woody perennial edible fruit bearing species in the agricultural landscapes of Amhara region. J. AgroforestSyst 78:79-95

25. Fajber, L. (1997). IDRC and Medicinal Plants: Priority Issues and Research Needs. A Summary Document. IDRC

26. FasilKibebew (2001). The status of availability of data of oral and written knowledge and traditional health care in Ethiopia. In: Conservation and Sustainable Use of Medicinal Plants in Ethiopia. MedhinZewdu and AbebeDemissie (Eds); Institute of Biodiversity Conservation and Research, Addis Ababa, Ethiopia, 2001; pp 107-119.

27. FAO (2010). Forests for Improved Nutrition and Food Security.

28. Gemedo D, Brigitte L, Maass, Johannes I: Plant biodiversity andethnobotany of Borana pastoralists in Southern Oromia,Ethiopia. Economic Botany 2005, 59(1):43-65.

29. Getachew Addis (2009). Wild and semi-wild edible plants of Hamar and Xonso (South Ethiopia) with emphasis on their ethno botany and nutritional composition of selected species. PhD Thesis Addis Ababa University.

30. Getachew Addis, KelbessaUrga\&DawitDikasso 2005. Ethnobotanical study of edible wild plants in some selected districts of Ethiopia. Human Ecology 33 (1): 83-118.

31. Getnechokole, 2011. An Ethnobotanical Study Of Plants Used In Traditional Medicine And As Wild Foods In And Around Tara Gedam And Amba Remnant Forests In LiboKemkemWereda, South Gonder Zone, Amhara Region, Ethiopia (published thesis) 
32. Gidey M, Teklehaymanot T, Animut A, Mekonnen Y: Medicinal plants of Shinasha, Agew-awi and Amhara peoples in northwest Ethiopia. J Ethnopharmacol2007, 110:516-525.

33. Grivetti, L. and Ogle, B. (2000). Value of traditional foods in meeting macro and micronutrient needs: the wild plant connection. J.Nutr. Res. Rev. 13: 31-46.

34. Guinand Y. \&DechassaLemessa 2000. Wild food plants in Southern Ethiopia: Reflections on the role of 'famine foods' at a time of drought. UNDP-EUE Field Mission Report, Addis Ababa, Ethiopia.

35. Haile Yineger and DelenasawYewhalaw (2007). Traditional medicinal plant knowledge and use by local healers in Sekoru District, Jimma Zone, Southwestern Ethiopia. Journal of Ethnobiology and Ethnomedicine 2007, 3:2

36. Haile Yineger, EnsermuKelbessa, TamratBekele and ErmiasLulekal (2008). Plants used in traditional management of human ailments at Bale Mountain National Park, Southeastern Ethiopia. J. Med. Plant. Res.2:132-153.

37. Hamilton, A. and Martin, W. (2002). People and Plants Handbook Issue 8 the Newsletter of People and Plants. WWF-UNESCO, Royal Botanical Garden, Knew.

38. Hamilton, A.C., Pei Shengji, Kessy, J., Khan, Ashiq A., Lagos-Witte, S. and Shinwari, Z.K (2003). The Purpose and Teaching of Applied Ethnobotany. People and Plants working paper 11. WWF, Godalming, UK.

39. Hedberg, I. (1993). Botanical methods in ethnopharmacology and the need for conservation of medicinal plants. J Ethnopharmacol1993, 38:121-128.

40. Jaenicke, H. and Hoschle-Zeledon, I. (eds.) (2006). Strategic framework for underutilized plant species research and development.Rome, Italy: ICUC, Colombo and Global Facilitation Unit for Underutilized Species.

41. Ju, Y., Zhuo, J., Liu B. and Long, C. (2013). Eating from the wild: diversity of wild edibleplants used by Tibetans in Shangri-laregion, Yunnan, China. Journal of Ethnobiology and Ethnomedicine, 9:28

42. KebuBalemie\&FassilKebebew 2006. Ethno-botanical study of wild edible plants in Derashe and Kucha Districts, South Ethiopia. Journalof Ethnobiology and Ethnomedicine2 (53):1-9.

43. Khasbagan and Soyolt (2008). Indigenous knowledge for plant species diversity: a case study ofwild plants' folk names used by the Mongolians in Ejina desert area, Inner Mongolia, P. R. China. Journal of Ethnobiology and Ethnomedicine 2008, 4:2

44. Mazhar, F., Buckles, D., Satheesh, P. V. and Akhter, F. (2007). Food sovereignty and uncultivated biodiversity in South Asia. Academic Foundation. New Delhi, India

45. Moa Megersa, (2010). Ethnobotanical Study of Medicinal Plants in WayuTukaWereda, East Wollega Zone of Oromia Region, Ethiopia. M.Sc. Thesis, Addis Ababa University, Addis Ababa.

46. Rathore, M. (2009). Nutrient content of important fruit trees from arid zone of Rajasthan. J. Hort. Forestry 1: 103-108.

47. Ruffo C.K., Birnie A. \&Tengnäs B. 2002. Edible wild plants of Tanzania. Regional land managementunit, SIDA, Nairobi, Kenya. Pp 766.

48. SeyoumGetaneh (2009). Ethnobotanical Studies of Medicinal Plants in DebreLibanosWreda, North Shewa Zone of Oromia Region, Ethiopia. M.Sc. Thesis, Addis Ababa Uiversity, Addis Ababa.

49. Stepp, J. R. and Moerman, D. E. (2001). The importance of weeds in ethnopharmacology. J. Ethnopharmacol2001, 75:19-23.

50. Stepp, J.R. (2004). The role of weeds as sources of pharmaceuticals. J. Ethnopharmacol2004, 92:163-166

51. Sofowora, A. (1993). Medicinal plants and traditional medicine in Africa. In: An ethnobotanical survey of medicinal plants in Babungo, Northwest Region, Cameroon. Journal of Ethnobiology and Ethnomedicine 2010, 6:8.

52. Somnasang, P. and Moreno-Black, G. (2000). Knowing, gathering and eating: knowledge and attribute about wild food in an Asian village in North-eastern Thailand. J. Ethnobiol. 20: 197-216.

53. Suminguit, S.V. (2005). Ethnobotanical Documentation: A User's Guide. International Fund for Agricultural Development (IFAD) through TAG 486 "Institutional Innovation Project" managed by the ICRAF.

54. TafesseMesfine and Mekonnen Lemma (2001). The role of traditional veterinary herbal medicine and its constraints in the animal health care system in Ethiopia. In: Conservation and Sustainable Use of Medicinal Plants in Ethiopia. MedhinZewdu and AbebeDemissie (Eds); Institute of Biodiversity Conservation and Research, Addis Ababa, Ethiopia, 2001; pp 22-28.

55. TilahunTeklehaymanot and MirutseGiday (2010). Ethnobotanical study of wild edible plants of Kara and Kewegosemipastoralist people in Lower Omo River valley, DebubOmo Zone, SNNPR, Ethiopia.Journal of Ethnobiologyand Ethnomedicine 6: 23.

56. TigistWondimu, ZemedeAsfaw\&EnsermuKelbessa 2006. Ethnobotanical study of food plants by the people in 'Dheeraa' town, Arsi, Ethiopia. SINET: Eth. J. Science 29: 71-80. 
57. UP (University of Pennsylvania) 2000. Wild food plants in Southern Ethiopia. Reflections on the role of famine foods at a time of drought. African study center, Addis Ababa, Ethiopia.

58. WHO (2003). Traditional Medicine. Fact Sheet No 134.

59. ZemedeAsfaw (1997). Indigenous African food crops and useful plants: Survey of indigenous food crops, their preparations and home gardens Nairobi: TheUnited Nation University Institute for Natural Resources in Africa;

60. ZemedeAsfaw\&MesfinTadesse 2001. Prospects for sustainable use and development of wild food plants in Ethiopia. Economic Botany 55: 47-62

APPENDECES:-

Appendix 1: List of medicinal and wild edible plants in the study area

\begin{tabular}{|c|c|c|}
\hline Scientific name & Family & Vernacular name \\
\hline Cordiaafricana Lam. & Boraginaceae & Abanga \\
\hline VernoniafiligeraOlivo\&Hiern & Asteraceae & Abibiqasi \\
\hline AnnonasenegalensisPers. & Annonaceae & Adegela \\
\hline Pseudocedrelakotschyi (Schweinf.) Harms & Meliaceae & Aduruba \\
\hline Tragiadoryodes M Gilber & Euphorbiaceae & Afanfalan \\
\hline LonchocarpuslaxiflorusGuill. \&Perr. & Fabaceae & Afud \\
\hline CombretummolleR. Br. ex G. Don & Combretaceae & Agerdha \\
\hline Flacourtiaindica (Burm.f.) Merr. & Flacourtiacaceae & Agnegnsheqe \\
\hline Adansoniadigitata $\mathrm{L}$. & Bombacaceae & Agungules \\
\hline Strychnosinnocua Del. & Loganiaceae & Ahulu \\
\hline Leonotisocymifolia (Burm.f) Lwarsson & Lamiaceae & Albegeniya \\
\hline Cyphostemma sp. & Vitaceae & Alhorimusha \\
\hline MeliaazedarachL. & Meliaceae & Almim \\
\hline ZiziphusmauritianaLam. & Rhamnaceae & Amurusam \\
\hline FicusOvataVahl. & Moraceae & Anemenu \\
\hline Sub Spmacrocarpum (Engl.) F. White & Myrtaceae & Anzum \\
\hline Gardenia ternifoliaSchum. \&Thonn. & Rubiaceae & Aqenda \\
\hline Stereospermumkunthianum Cham & Bignoniaceae & Aqulqa \\
\hline RicinuscommunisL. & Euphorbiaceae & Ashenshemuke \\
\hline Terminalialaxiflora Engl. \& Diels & Combretaceae & Ashihur \\
\hline Clematis 203orrid203Perro\&Guill & Ranunculaceae & Ashurbalu \\
\hline Abelmoschussp. & Malvaceae & Asidhisidhi \\
\hline IndigoferaspicataForssk & Fabaceae & Atahuna \\
\hline Vitexdoniana Sweet. & Verbenaceae & Atsoda \\
\hline ZiziphusabyssinicaHochst. ex A. Rich. & Rhamnaceae & Atsomendu \\
\hline Carissa spinarum $\mathrm{L}$. & Apocynaceae & Ayon \\
\hline Ximenia Americana L. & Olacaceae & Bibi \\
\hline Saba comorensis (Boj.) Pichon & Apocynaceae & Bishqor \\
\hline Syzygiumguineense (Wild.) Dc. Subsp & Myrtaceae & Bulumitse \\
\hline Dombeya203orrid(J. F. Gmel.) P. Bamps & Sterculiaceae & Deder \\
\hline Sennaobtusifolia(L.) Irwin \&Barneby & Fabaceae & Dehelare \\
\hline Ozoroapulcherrima(Schweinf.) R \& A Fernandes & Anacardiaceae & Dudumugu \\
\hline ClerodendrumalatumGüerke & Lamiaceae & Dudushigniru \\
\hline AchyranthusasperaL. & Amaranthaceae & Dumugelo \\
\hline MomordicafoetidaSchum & Cucurbitaceae & Fesh \\
\hline Albiziamalacophylla (A. Rich.) Walp. & Fabaceae & Gendher \\
\hline Cymbopogoncaesius (Hook. \&Arn.) Stapf & Poaceae & GneraWoni \\
\hline Grewiavelutina (Forssk.) Vah & Tiliaceae & HornotseGelu \\
\hline GrewiamollisA.Juss & Tiliaceae & Hurinotse \\
\hline GrewiatrichocarpaHochst ex A. Rich. & Tiliaceae & Horgnatse \\
\hline Tamarindusindica $\mathrm{L}$. & Fabaceae & Mala \\
\hline Peponiumsp. & Cucurbitaceae & Marupha \\
\hline
\end{tabular}




\begin{tabular}{|c|c|c|}
\hline Piliostigmathonningii (Schum.) Milne-Redh. & Fabaceae & Megel \\
\hline Ampelocissusbombycina (Bak.) Planch. & Vitaceae & Mengogo \\
\hline Sidarhombifolia $\mathrm{L}$. & Malvaceae & Meshenheni \\
\hline Rhusquartiniana A. Rich. & Anacardiaceae & Metsebelelo \\
\hline Acacia spp. & Fabaceae & Mezel \\
\hline Asparagus flagellaris (Kunth) Baker & Asparagaceae & Moro \\
\hline Ficussycomorus L. & Moraceae & Neyisha \\
\hline Balanitesaegyptiaca (L) Del. & Balanitaceae & Qaha \\
\hline DioscoreaschimperianaKunth & Dioscoreaceae & Qayita \\
\hline Anogeissusleiocarpa (A. DC.) Guill. \&Perr. & Combretaceae & Qey \\
\hline Abelmoschus esculents (L.) Moench & Malvaceae & Qenqetse \\
\hline Pterolobiumstellatum(Forssk) Brenan & Fabaceae & Qudu \\
\hline Lanneafruticosa (Hochst.exA.Rich.) Engl & Anacardiaceae & Quwa \\
\hline Crassocephalumrubens (jacq.) S. Moore & Asteraceae & Shaqadona \\
\hline SecuridacalongepedunculataFresen. & Polygalaceae & Sheqet \\
\hline Phoenix reclinataJacq & Arecaceae & Shibe \\
\hline DalbergiaboehmiiTuab. & Fabaceae & Tsaba \\
\hline Ficus thinning Blume. & Moraceae & Tseera \\
\hline
\end{tabular}

